\title{
Environmental management and sustainable tourism development: The case of hotels in Greater Accra Region (GAR) of Ghana
}

Received (in revised form): 9 August 2006

\section{Ishmael Mensah}

holds an MPhil degree in Tourism from the University of Cape Coast, Ghana and a Certified Hospitality Educator by the American Hotel and Lodging Association. He teaches tourism and hospitality management at the Department of Geography and Tourism, University of Cape Coast. His research interests are in events management, sustainable tourism, destination marketing and service quality in hospitality.

\begin{abstract}
Due to calls for more sustainable tourism practices, environmental management, which was the preserve of the smokestack industries, has engaged managers of most hotels around the globe. The literature is replete with environmental management practices and initiatives by hotels in North America, Europe and Asia and therefore not much is known about environmental management in hotels in a developing country like Ghana. This article therefore explores the environmental management and sustainable tourism practices in hotels in Ghana based on a survey of 52 managers of various categories of hotels in the Greater Accra Region of Ghana.
\end{abstract}

\section{Keywords:}

hotels, environmental management, sustainable tourism, eco-labels, Africa, Ghana

Journal of Retail and Leisure Property (2007) 6, 15-22. doi:10.1057/palgrave.rlp.5100039

Ishmael Mensah Department of Geography and Tourism University of Cape Coast Cape coast, Ghana Tel: +2334230680 Fax: +2334233172 E-mail: aprakof@yahoo.com

\section{INTRODUCTION}

Management of the environment has become a critical issue for the hotel industry in the wake of calls for sustainable tourism development and growing environmental awareness among tourists, governments and associations. Consequently, the green hotel movement and ecotourism have become trends in the tourism industry. ${ }^{1}$ As a new trend, environmental management has been vigorously pursued especially by multinational hotels and has given birth to international and regional initiatives, certification schemes and the awarding of eco-labels. 
Eco-labels and certification schemes have been used to encourage the development of less-damaging and environmentally friendly hotels as well as to educate the customer. Eco-labelling started in Europe in 1985 with the Blue Flag scheme; however, the concept has been adopted by the tourism and hospitality industry to promote a clean and green image. There are now over 100 eco-label and certification schemes operating in different parts of the world today.

Sustainable tourism emanates from the Brundtland Commission's report, 'our common future'. ${ }^{2}$ It is a term that has been widely abused by the industry and hence lacks a precise definition. However, sustainability when applied to the tourism industry means the use of tourism resources would have to be regulated so that they are not consumed, depleted or polluted in such a way as not to be available for use by future generations of tourists. ${ }^{3}$ Sustainability therefore underpins environmental management in hotels, since sound environmental management practices will invariably culminate in a sustained tourism industry.

In the 1980s, the word 'sustainability' gained currency, with the formulation of the World Conservation Strategy and the World Commission on Environment and Development (WCED). Sustainability, however, defies a precise definition. It is also difficult to implement practically or operationally. ${ }^{4}$ On account of this difficulty, sustainability has been defined in various ways. The most widely quoted definition, however, is the one by the WCED in the Brundtland Report of 1987, the 'development that meets the needs of the present without compromising the ability of future generations to meet their own needs'. ${ }^{2}$

Growing concerns over the impacts of tourism on the environment have led to the tourism industry embracing the concept of sustainability. ${ }^{5,6}$ Sustainable tourism, however, remains a barrage of principles and case studies that guide tourism development at various levels, from large resorts to limited size special interest tourism. The current trend therefore has been a paradigm shift in the industry from mass tourism and other unsustainable tourism practices to sustainable tourism development.

Just like the word 'sustainability' however, the Sustainable Tourism Development concept is also hard to operationalise and that there is yet no consensus on what it means, let alone how to implement a sustainable tourism policy. ${ }^{7}$ Although, there seems to be agreement on the need for tourism resources to be made available for the enjoyment of future generations. In effect, the industry must ameliorate the impacts of tourism on the environment, and reduce the consumption of natural resources for Sustainable Tourism Development to be achieved.

The industry has also responded to the growing importance of the notion of the use of the term 'sustainability' in a range of ways including industrial regulation, environmental auditing, consultation and codes of conduct. ${ }^{8}$ There is, however, a school of thought that the use of the word 'sustainability' by the tourism industry is often little more than a marketing gimmick. ${ }^{9}$ 


\section{ENVIRONMENTAL MANAGEMENT FOR SUSTAINABLE TOURISM DEVELOPMENT}

That notwithstanding, most of the environmental management programmes in hotels have been occasioned by the quest for sustainable tourism development. In the context of the hotel industry, it is not possible to understand the importance of the natural environment for hotels and the tourism industry; without bringing in a discussion of development generally and sustainable development in particular. It is therefore imperative for environmental management in hotels to be placed within the framework of sustainable tourism development. ${ }^{10}$

The EPA of Ghana defines Environmental Management as 'the process by which the collection of policies, structures, resources, systems and processes are brought to mutual interplay for the achievement of clearly defined environmental policy directives'. ${ }^{11}$ Environmental management practices in hotels have been geared towards energy conservation, water conservation, reduction of waste and establishing good relations with local communities. It is as a result of cost savings waste management and energy and water savings have become popular environmental management practices. As managers have come to the realisation that they could save on their water and energy bill when they adopt good conservation practices. There are examples of transportation companies, hotels and restaurants haven taken steps to recycle and reduce the consumption of energy, thereby reducing costs, increasing profits and taking some steps towards sustainability. ${ }^{9}$

In spite of the growing popularity of environmental management in hotels, only larger hotels have been found to be at the forefront of environmental management. ${ }^{8,12}$ Nonetheless, it has been realised that sound environmental management is beneficial to all hotels, as it results in profitability, customer retention, improved corporate image and cost savings among others.

\section{IMPACTS OF HOTELS ON THE ENVIRONMENT}

In spite of the apparent positive impacts of hotels, they also exert pressure on the environment of destinations, sometimes with dire consequences. Most of the studies on the impacts of hotels on the environment have been conducted on coastal and island resorts. Here, the impacts on the host community have been the focus. In the Mediterranean, hotels could easily consume 400 litres of water per guest per day while locals may only require 701 per day. ${ }^{13}$ Hotels have also taken valuable land away from local communities. In Nepal, 400,000 hectares of forest were cleared each year to construct hotels, lodges and furniture manufacturing, to provide fuel for cooking and for hot showers and campfires, ${ }^{14}$ which led to increased risk of landslides and flooding. Hotels have also contributed to the depletion of energy resources. Through their operations, hotels generate lots of solid and liquid waste, which are discharged into water bodies and other unapproved places or are expensive to manage. ${ }^{15}$ 


\section{ENVIRONMENTAL MANAGEMENT IN HOTELS}

A number of hotels are now taking environmental issues seriously and are embarking on activities like recycling, water and energy conservation, environmental education, waste management and afforestation (the planting of trees). The growing environmental consciousness in the industry can be attributed to government regulation, changing consumer demand, advocacy and initiatives by Non-governmental Organisations (NGOs) and ethics by professional associations. Studies conducted by the International Hotels Environment Initiative (IHEI) and Accor revealed that 90 per cent of hotel guests preferred to stay in a hotel that cared for the environment. ${ }^{16}$ Environmental management in hotels also reflects a paradigm shift in the industry from mass tourism to sustainable tourism. It is a continuous process adopted through management decisions, through which an organisation's activities are monitored and appropriate programmes devised to reduce the negative environmental impacts.

There are many examples of hotels taking specific initiatives to reduce the impacts of their operations on the host community. An EU funded hotel construction project in Western Samoa used traditional designs and techniques and only imported materials where local substitutes could not be produced. The hotel sites are owned by local villagers, local people are employed and local agricultural produce are consumed by tourists. ${ }^{14}$ Also Grecotel, the largest hotel chain in Greece uses only local styles and materials in architecture and facilities design. The hotel also sustains the local economy, serves local dishes and encourages environmental conservation, as well as encouraging guests to visit smaller villages. ${ }^{17}$ Moreover, one of the NOVOTEL and Hotel Ibis initiatives at Homebush Bay in Sydney, Australia is the reduction of portable water by 50 per cent through a dual piping system. ${ }^{18}$ At the Kingfisher Bay and Village (KBRV) in Queensland Australia, architectural design and use of fluorescent bulbs allow for minimal energy consumption. ${ }^{10}$

\section{PROBLEMS AND OBJECTIVES}

In Ghana, the tourism industry is growing at the rate of 3.5 per cent per annum and it has been projected that tourism receipts that stood at $\$ 248.80 \mathrm{~m}$ in 1996 will reach $\$ 1.562 .06 \mathrm{~m}$ by the year $2010 .{ }^{19}$ The hotel sector in Ghana has experienced a rapid growth in response to the growing tourist trade and the opportunities offered by prudent macroeconomic policies. The result is the rapid growth in hotels. The Greater Accra Region (GAR) has the largest number of hotels.

Approximately 34 per cent of all rooms existed in the GAR including all the four and five star hotels in 2001. ${ }^{20}$

The phenomenal growth of hotels in the region has sparked some concerns about their environmental impacts. As noted in the 1996 Tourism Development Plan for the GAR, sewage and solid waste disposal is a problem in some hotels. Among other things, the plan expresses concern about pollution of rivers, lakes and coastal water from sewerage and solid waste disposal systems in hotels and other facilities. ${ }^{21}$

The literature is replete with environmental management practices and initiatives by hotels in North America, Europe and Asia, and therefore not 
much is known about environmental management in hotels in a developing country like Ghana. It is in this vein that this paper looks at how hotels in GAR are embarking on environmental management and sustainable tourism practices.

\section{METHODOLOGY}

The data presented here are part of a larger study conducted on Environmental Management Practices in Hotels in the Greater Accra Region of Ghana. The questionnaire elicited information on environmental management practices, perceptions of sustainable tourism, the nature of the hotel facility; including hotel classification, ownership type, services offered and staff strength as well as on their socioeconomic characteristics, such as their age, sex, educational background and income.

The target population comprised all hotel managers in the GAR as at February 2003. The Ghana Tourist Board (GTB) list of 592 licensed hotels in the GAR for 2002 served as the sampling frame. Both probability and nonprobability methods were employed in the selection of the various samples of managers, guests and local residents.

First, the stratified random sampling method was used to select the hotel managers. The criterion for the strata was the hotel classification system used by the GTB (Table 1). Hotel managers were randomly selected from each stratum to arrive at the sample size $(n=52)$. Hotels in each stratum were numbered and random numbers used to pick from the various strata.

\section{RESULTS OF SURVEY}

Observation of environmental and sustainable tourism practices revealed that the most popular eco-friendly practices in the GAR (Figure 1) were use of energy-efficient light bulbs (94.2 per cent), the reuse of linen and towels ( 74 per cent), training of staff to be eco-friendly ( 72 per cent), the use of eco-friendly cleaning products (72 per cent) and support for the local community (70 per cent). Since all hotels want to cut overheads in order to remain profitable and competitive, the use of energy-efficient light bulbs and re-use of linen and towels were the two most popular costcutting measures, which accounted for their adoption by most hotels.

Table I: Sample of hotel managers

\begin{tabular}{lcc}
\hline Category/class & Total & Sample of hotel managers \\
\hline 4-5 Star & 4 & 4 \\
3 Star & 10 & 8 \\
2 Star & 58 & 10 \\
I Star & 60 & 10 \\
Guest house & 75 & 10 \\
Budget & 380 & 10 \\
Unclassed & 4 & - \\
& 592 & 52 \\
\hline
\end{tabular}

Source: Fieldwork (2003) 


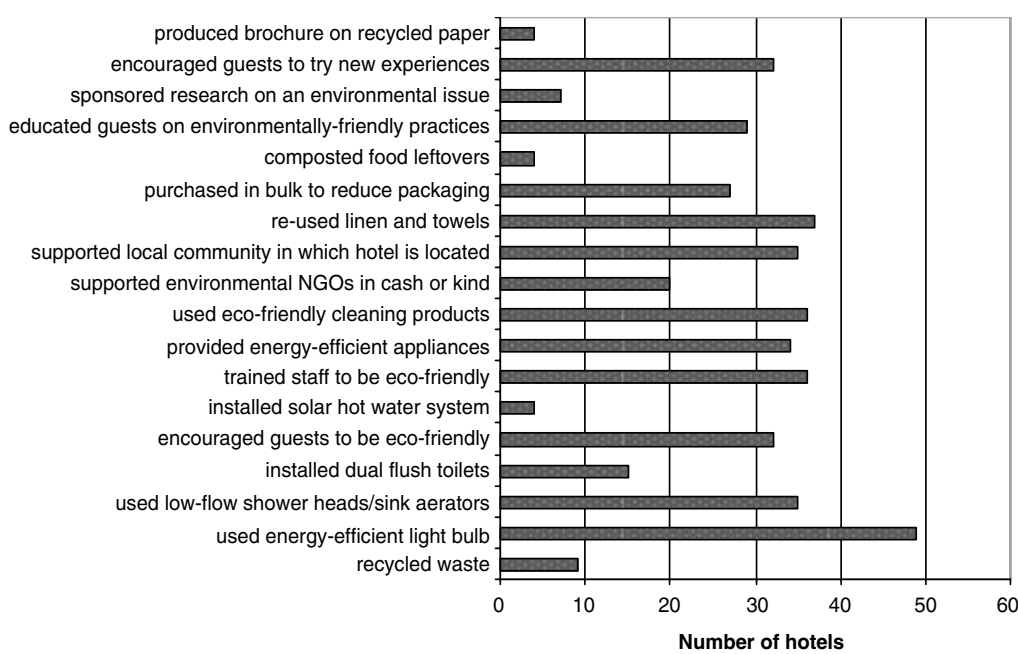

Figure I: EMP and sustainable tourism practices of hotels

Saving on energy cost as a result of using energy efficient light bulbs and appliances and less frequent changing linen and towels are two ways of saving costs in a hotel. Less use of air conditioners however, which is also a deliberate energy cost saving measure, is not popular particularly among the star-rated hotels, which only infrequently shut down their air conditioners in order to conserve energy. Although the Electricity Company of Ghana (ECG) charges a penalty for maximum energy demand air conditioning is always on in the receptions of most of the star-rated hotels for the comfort of guests.

To some extent, the use of alternative energy sources such as use of LPG gas for cooking was prevalent in the hotels visited. The reason was that it was relatively cheaper to use LPG gas rather than electricity. Only 8 per cent of the hotels had installed solar hot water heating systems.

Water conservation was another area of environmental management that was popular among hotels as a cost-saving measure. About 67.3 per cent of the hotels use low-flow shower heads and sink aerators. Barely 28.8 per cent of the hotels were adopting the dual flush system however, perhaps because this technology was less known in Ghana.

The hotels were also alive to their social responsibilities. Seventy per cent of the hotels had supported the local communities in which hotels were located. The support was in the form of infrastructural development, sponsorship of local events and donations. Some hotels had constructed roads, embarked on afforestation programmes and provided cash and logistical support for local festivals and other events. In terms of support for local NGOs however, less than half of the hotels had supported them in cash or in kind.

The least popular eco-friendly practices in the hotels were recycling of waste (17.3 per cent), use of solar energy and composting of food waste ( 8 per cent). Some of the managers claimed recycling was expensive, was not their core business and that they also did not have the technology recycle. One exception was the NOVOTEL chain where recycling has been given serious consideration with separate recycling bins for plastic, metals, bottles and paper in offices and kitchens. 


\section{CONCLUSIONS}

From the results of this survey, it is concluded that the majority of managers of hotels in Accra are inactive in the areas of recycling and use of solar energy although some larger multinational hotels are more proactive like their Western counterparts in Europe and North America. They usually engaged in environmental management activities and sustainable tourism practices aimed at ensuring a clean, green and healthy environment. The most popular environmental management and sustainable tourism practices of the hotels were use of energy-efficient light bulbs and re-use of linen and towels. This study was, however, exploratory and did not delve deep into the reasons for hotels' activity or inactivity in environmental management.

\section{RECOMMENDATIONS}

It is recommended that the GTB, Environmental Protection Agency (EPA), Accra Metropolitan Assembly (AMA) and other institutions tasked with enforcing environmental standards should organise training programmes for hotel managers on sound environmental management practices. The training should cover areas like hotels purchasing policies, recycling of waste, government's environmental requirements, national environmental policy and the benefits to be derived from sound environmental practices among others. Such programmes will adequately inform hotel managers about their responsibilities and help them to pursue suitable environmental management programmes.

Secondly, education of guests and staff on environmentally responsible behaviour should be a major preoccupation of hotels. Laudable efforts of managers could come to nothing if guests and workers, who are major players in the hotel environment are not included. Guests could be educated through brochures, posters and signs into efficient water and energy conservation; respect for local cultures; and proper waste disposal. Hotel workers should also be educated on environmentally responsible management and marketing practices as part of their induction. They should also be constantly updated on current environmental management trends in the industry.

Finally, recycling of waste must be an important environmental management programme of hotels. Hotels must recycle the thousands of tons of wastewater that goes down the drain each day. Wastewater could be used to water ornamental plants around the hotels or to flush toilets. Food leftovers can be used for composting as manure or to feed animals. Recycling of solid waste demands some form of technology, which should not be beyond the collective scope of these hotels. They should in their own small way have, however, separate dustbins for collecting papers, plastic and bottles to make easier, the work of waste management companies involved in recycling.

\section{References}

1. Olsen, M. D., Ching-Yick Tse, E. \& West, J. J. (1998). Strategic Management in the Hospitality Industry, 2nd edn, John Wiley and Sons Inc., New York.

2. Bruntland, G. (ed.) (1987). Our Common Future: The World Commission on Environment and Development, Oxford University Press, Oxford. 
3. Burton, R. (1995). Travel Geography, 2nd edn, Pitman Publishing, London, p.142.

4. McCool, S. F. (1994). Linking tourism and the environment and concepts of sustainability: setting the stage, in McCool, S.F. \& Watson, A.E., (eds.) Linking Tourism, the Environment and Sustainability: Tropical Volume of Compiled Papers from a Special Session of the Annual Meeting of the National Recreation and Park Association, 1994, US, Department of Agriculture, pp. 3-7.

5. Wall, G. (1997). Sustainable tourism-unsustainable development, in Wahab, S. \& Pigram, J.J. (eds.) Tourism Development and Growth, the Challenges of Sustainability, Routledge, New York p. 44.

6. Kirk, D. (1998). Attitudes to environmental management held by a group of hotel managers in Edinburgh. International Journal of Hospitality Management. 17, 33-47.

7. Gartner, W. C. (1997). Image and Sustainable Tourism Systems, in Wahab S.and Pigram J.J. (eds.) Tourism Development and Growth: The Challenge of Sustainability, Routledge, New York, pp. $179-180$.

8. Mauforth, M. \& Munt, I. (1998). Tourism and Sustainability, New Tourism in the Third World, Routledge, New York.

9. Hawkes, S. \& Williams, P. (1993). The Greening of Tourism; From Principles to Practice, in GLOBE ' 92 Tourism Stream, Casebook of Best Practice in Sustainable Tourism, Centre for Tourism Policy and Research, Burnaby, BC, Simon Fraser University.

10. Faulk, S. E. (2000). A Survey of Environmental Management by Hotels and Related Tourism Businesses, A presentation at Oikos PhD. Summer Academy, University of St Gallen, Switzerland, pp. 3-6, 11-17.

11. Environmental Protection Agency (1997). Environmental Protection Agency Newsletter, Vol. 1, No. 7, October-December.

12. Wahab, S. \& Pigram, J. J. (1997). Sustainable tourism in a changing world in Wahab, S., \& Pigram, J.J. (eds.) Tourism Development and Growth, the Challenges of Sustainability, Routledge, New York p.19.

13. Hunter, C. \& Green, H. (1995). Tourism and the Environment, a Sustainable Relationship?, Routledge, New York, pp. 19-24.

14. Eber, S. (ed). (1992), Beyond the green horizon, principles for sustainable tourism, a discussion paper commissioned from Tourism Concern by WWF, UK, pp. 10-31.

15. Mathieson, A. \& Wall, G. (1982). Tourism: Economic, Physical and Social Impacts, Harlow: Longman, p.173.

16. Hotel Online Special Report (2000). Environmental Survey Shows Growing Importance of Environment for Hotel Guests. [On-line]Available: http://WWW.hotelonline.com/News/2000-3rd/ Sept00-EnvironmentGuests.html.

17. Middleton, V. T. C. \& Hawkins, R. (1998). Sustainable tourism: a marketing perspective, ButterWorth-Heinemann, UK, pp. 134-139, 148-152.

18. Hotel Online Special Report (2002). Consumer attitudes towards the role of hotels in environmental sustainability/international hotels environment initiative research.[On-line]Available: http:// WWW.hotel-online.com/News/PR2002-3rd/Jul02-IHEI.html.

19. Ghana Tourist Board (2005). Ghana Tourism Statistical Factsheet, GTB, Accra.

20. Ghana Tourist Board (2002). List of Recommended Hotels, 2002, GTB, Accra.

21. Ministry of Tourism (1996). Tourism Development Plan for the Greater Accra Region, Accra, MOT, UNDP. 